\title{
The Territory of Traditional Nature Use as a Specific Territorial Unit in the System of Territorial Division of the North, Siberia and the Russian Far East
}

\author{
Andrey A. Kondrashev, Olga V. Ronzhina \\ and Alexandra B. Zenkina* \\ Siberian Federal University \\ 79 Svobodny, Krasnoyarsk, 660041, Russia
}

Received 01.09.2018, received in revised form 12.09.2018, accepted 26.09.2018

\begin{abstract}
New proposals of the Government of the Russian Federation on reorganisation of the territories with traditional nature use by indigenous peoples require analysis and discussion among the scientific community. The legislative model of federal, regional and municipal territory with traditional nature use are developed and described by applying comparative law tools. Through the methods of statistical analysis, emerging tendencies on actual implementation of the rights of indigenous peoples to use the land and other natural resources within the borders of these areas and within the territories of their native residence, which are not considered to be territories of traditional nature use legally, are illustrated. For the new economic environment in Russia, which is oriented on increasing exploration of the North resources, it is necessary to back up exercising of the rights of indigenous minorities guaranteed by the Article 69 of the Constitution of the Russian Federation. In particular, on the federal level there should be established general principle characteristics of the legal regime on the territory with traditional nature use similar to a subject in the territorial division of the Russian Federation. The integral legal regime of the territories with traditional nature use should include obligatory formation of such territorial units in the settlements of indigenous peoples, taking into account the current land and other natural resources management within the traditional economy as well as creation of a set of constraints in the others' economic activity, primarily, subsoil users and timber producers, within the territories with traditional nature use. The use of natural resources based on payment, authorization and licensing should be abolished for the indigenous peoples living in the territories with traditional nature use. It follows from the declaration of specific property right - an ethno-communal, non-marketed form of ownership of indigenous peoples of the land and other natural resources (another form of ownership provided by the Article 9(2) of the Constitution of the Russian Federation).
\end{abstract}

Keywords: indigenous peoples, territories with traditional nature use, Arctic Region, North, territorial division, form of ownership.

(C) Siberian Federal University. All rights reserved

* Corresponding author E-mail address: sashalitv@yandex.ru

This work is licensed under a Creative Commons Attribution-NonCommercial 4.0 International License (CC BY-NC 4.0). 
The article represents a part of the academic research No. 17-13-24004 "Legal regulation of the state and municipal division of the Northern territories of Krasnoyarskiy Krai (including areas of indigenous peoples residence) aimed at their sustainable social and economic development" under the Grant by the Russian Foundation of Fundamental Research, the Government of Krasnoyarskiy Krai, the Foundation of Scientific and Technological Activity of Krasnoyarskiy Krai, and with the legal support of the legal reference system "Consultant-Plus".

Research area: law.

Citation: Kondrashev, A.A., Ronzhina, O.V., Zenkina, A.B. (2018). The territory of traditional nature use as a specific territorial unit in the system of territorial division of the North, Siberia and the Russian Far East. J. Sib. Fed. Univ. Humanit. soc. sci., 11(10), 1572-1592. DOI: $10.17516 / 1997-1370-0322$.

Introduction to the research problem. Territories of traditional nature use appeared in the Russian legislation in 1992 with the purpose of ensuring rights of indigenous peoples. Under the decree of the President of the Russian Federation (Ukaz Prezidenta..., 1992) 518 territories of traditional nature use (TTNU) were formed. In 2001 the Federal Law of 07.05.2001, No. 49-FZ “On territories of traditional nature use of Indigenous Peoples of the North, Siberia and the Far East of the Russian Federation" (Federal'nyi Zakon, 2001, further - FL-49) was enacted. Further amendments to this law and the practice of its enforcement formed at this point are accessed in the national doctrine as a roll-back of legal guarantees of indigenous peoples on the resources and the territories of their residence (Kriazhkov, Ragulina (2009), Gogolev \& Maiakunov (2017), Vlasova, Kaplin \& Volkov (2018), Iakel' (2012)).

Under FL-49 only TTNU of regional and municipal significance were established. Not even one territory was created on a federal level. For the last 20 years, all appeals from organisations of indigenous peoples requesting to form TTNU were not successful. When reviewing denials in the formation of TTNU of a regional or municipal significance the courts simply oblige public authorities to re-examine a case (see e.g. Reshenie 21.02.2014). All judicial decisions in connection with denials of executive authorities in establishing TTNU were not in favour of indigenous peoples (Novikova, Iakel', 2006: 13; Zuev, 2014: 56).

A majority of national scholars (Andrichenko, 2014: 244; Grigorieva, 2016: 41; Poddubikov, 2012: 137; Tranin, 2010: 41, Koptseva, 2017: 32) and practitioners, including regional Ombudsmen for Rights of Indigenous Peoples, negatively assess Russian legislation regulating rights of indigenous peoples on land and other natural resources. Established practice in applying the law and judicial practice demonstrate that members of indigenous minorities generally get access to natural resources on a non- 
preferential basis (hunting and fishing). "Traditional way of life and economic activity do not provide an opportunity to gain profit sufficient for purchasing a land lot on an equal basis with other auction participants" (Filant, 2016: 89). This makes indigenous peoples particularly vulnerable in competition not only with major corporations but also with medium-sized enterprises, and places them on the edge of survival.

A part of places of indigenous residence is already being used by industrial enterprises. The rate of occupation and development of northern land by energy providers and mining companies has been growing during the past decades, therefore, contradictions between economic agents of re-industrialisation in Siberia, subsurface users, and indigenous minorities will deepen (Koptseva, 2017: 32). In some territorial entities of the Russian Federation, "more than $40 \%$ of the land that indigenous peoples considered to be their family and tribal lands for centuries are expropriated for subsurface use" (Danilova, 2008: 66). For example, when forming TTNU in Kachugskiy district in 2014, it was indicated that deforestation (47\% of territory are leased in this region) causes environmental disorder and destruction of life environment of the Evenkis (Postanovlenie 704), but public authorities legalised commercial timber harvesting in this area instead of placing restrictions on it. Without regard to indigenous rights millions of hectares of the Evenkis taiga, with no public auctions or tenders taking place, were given to companies of a state corporation Bank for Foreign Economic Activity (Vnesheconombank) (Vlasova, Kaplin, Volkov, 2018: 11).

Industrial interests in profit maximisation, "thirst for oil" (Prochazka, 2017), a wish for "vicious enrichment by means of northern fortunes and at the expense of people that live simply and unpretentiously in the far north" (Doklad Upolnomochennogo po pravam..., 2015) are put before the constitutional value of safeguarding indigenous way of life, based on a unique connection of aborigines with the fragile nature of the Arctic. TTNU formation was barely realised, running up against fronted interests of oil-extracting, mining and logging corporations. The discussion on the reassessment of policy on TTNU formation during a visiting meeting of the Governor of the KhantyMansi Autonomous District is significant in this matter. Such a large number of TTNU creates serious problems for the oil industry. Oil producers planning to place their objects within TTNU faced objections from the indigenous community (Obzor, 2017). TTNU also creates additional administrative burden and lowers investment attractiveness in the region (Filant, 2016: 90). Similarly, in the Krasnoyarsk Region public authorities equally value investment and industrial development of the region and rights of indigenous peoples to form TTNU (Postanovlenie 421). 
Though in some territorial entities of Russian Federation there are regulations requiring the participation of representatives of indigenous minorities in making a decision to provide lands of TTNU for industrial use, it is often doubtful that their consent is voluntary and informed. This statement is supported by judicial practice. Thus, construction of production facilities and winter high-ways on the territories of tribal lands were executed in accordance with the industrial allocation scheme approved by the indigenous community. However, OOO Juzhno-Sardakovskoe had to take legal action seeking to oblige members of indigenous minority groups to stop creating obstacles for construction and exploitation of a winter high-way and wells (Reshenie 20.11.2015).

The absence of preferential advantages for obtaining access to natural resources causes undue hardship for realisation of the main right of indigenous peoples of the North to carry out traditional economic activity. The following judicial decisions are representative. The indigenous community of the Tofalars "Barbitay" performs traditional economic activities: hunting, fishing, animal husbandry including deer and horse husbandry. The community owns reindeer that migrate from place to place depending on the season. In a parcel of a forested land members of the community built eight doghouses and a log hut (sized 3x4 meters) in order to live there for the following 2 or 3 years during which deer will have enough feed on this territory. The buildings are temporarily used by the community members for living at the sites of reindeer herdsmen, hunters, and fishermen. They are easily knocked down and transferred with the change of seasons and deer pastures. Nevertheless, the court obliged Tofalars to clear the territory from constructions, put the forested parcel to the initial state as the legislation does not entitle indigenous peoples for such use of land (Reshenie 24.12.2014, Opredelenie 25.03.2015, Reshenie 30.09.2015).

Evenkis communes of indigenous peoples "Oochami", "Kunnoeer", "Madra" rented parcels of forested land in remote and inaccessible taiga areas in conditions of eternal frost, covered by a range of mountains, small and large swamps, rivers and streams. The Ministry of Natural Resources of Krasnoyarsk Region demanded that the communities establish fire lines around settlements (most likely, around hunting boxes) and purchase tractors, power pumps, and fire-hoses as fire prevention measures. With no roads and in conditions of vulnerability of the soil and the vegetative cover the transportation of heavy equipment seems to be almost unpractical even for short distances, and the transportation of a heavy tractor with equipment is impossible. It will not be difficult to drown a tractor in the very first swamp. Moreover, the price 
of such fire protection equipment massively exceeds all available property of the said communes (Doklad Upolnomochennogo po pravam..., 2016).

Conceptual basis of the research. The legal substance of a Russian legal doctrine of a "territory of a traditional nature use" developed under the great influence of international principles of indigenous peoples rights. They are based on the norms of international law, the practice of international and national courts, legal approaches of international institutions. Russia guarantees rights of indigenous minorities in compliance with the generally accepted principles and norms of international law and international agreements of the Russian Federation (Article 69 of the Constitution of the Russian Federation). Norms of the ILO Convention No. 169 concerning Indigenous and Tribal Peoples signed in 1989 and not ratified by the Russian Federation, Convention on Biological Diversity signed in 1992 and ratified by the Russian Federation, the United Nations Declaration on the Rights of Indigenous Peoples (adopted by the General Assembly on 13 September 2007 (A/RES/61/295) direct the development of national legal systems. On their basis, national courts conclude that the state is under an obligation to ensure legal recognition and protection of lands, territories, and resources, which have been traditionally occupied by indigenous peoples, to define borders of such territories, indicate them and transfer the ownership to indigenous communities (Byurgorg-Larsen, 2014: 113). Indigenous peoples, who have been illegally banished from ancestral lands, are entitled to either occupation or just compensation for violated rights. A long-term absence of officially registered rights to land makes ownership rights more vulnerable before claims of third parties or even a state because there are no expressly stated borders of the territory of indigenous peoples. The problem is compounded by the fact that the scope of collective property and the abilities of its disposition are ambiguous. In case of granting of alternative land the collective property right arises at the moment of the transfer of such property (Parra, Tarre, 2016: 9-12).

The international community standpoint on defining the rights of indigenous people of the Arctic to land also derives from the theory of circumpolar civilisation. The way of life of indigenous peoples of the Arctic is based on a special geo-biological symbiosis of a natural landscape with its resources and an aboriginal inhabitant (Kurikov, Dyatlova, Khaknazarov, 2016: 73). According to their view of the world, the territory of residence is sacred, i.e. haunted by ancestors and nature spirits, which creates a system of taboo aimed at preserving the balance of natural forces and resources (Korennyie i malochislennyye..., 2012: 391). "The land is deemed to be spiritualised 
and all activity connected to the extraction of minerals may hurt it. Owning the land or seeing it as a product, which may be used, is seen as a crime" (Indigenous Peoples..., 1987: 69).

The methodology of the research. Using comparative law tools a legislative model of a federal, a regional and a municipal TTNU has been developed and described. Applying methods of statistical analysis emerging tendencies of actual exercise of rights of indigenous peoples to the use of land and other natural resources within the borders of such formed territories and within the territories of native residence, which are not legally considered to be TTNU, are illustrated. Defining TTNU as a structural element allowed, using comprehensive methods and a top-down approach, to substantiate guiding principles of a legal regime of a TTNU that shall be enshrined in the Russian legislation.

Statement of the problem. Russia adopts modern foreign technologies that allow for the cost-effective development of Arctic natural resources. However, Russian Government backs down under pressure of large national and international industrial corporations and is betraying constitutional values: preservation of a unique nature of the Arctic for future generations, recognition of TTNU as inalienable property of indigenous peoples. It is obvious that statutory regulation of rights of indigenous peoples to the use of natural resources within the territory of indigenous residence requires fast and substantial change. The objective of Russian Constitutional law theory is to outline the principal characteristics of a legal regime of TTNU, that would not be possible for a Russian legislator to ignore, based on generally accepted international doctrine. For the new economic environment in Russia, which is oriented on the accelerated exploration of resources of the North, it is necessary to provide a background for the exercise of rights of indigenous minorities guaranteed by Article 69 of the Constitution of the Russian Federation.

Is it possible to guarantee exclusive rights of indigenous peoples to a traditional way of life and conducting traditional economic activity within the frame of existing legal doctrine of TTNU? It is necessary to determine the legal nature of TTNU and the core characteristics of a legal regime including the procedure of establishing the territories, property rights of indigenous peoples to land and other natural resources within the borders of such territories.

Discussion. A. The legal nature and the legal regime of TTNU. It is a widespread opinion in Russian legal theory that from the viewpoint of the juridical subject matter TTNU is a land lot (with other natural resources within its borders) to which indigenous 
peoples are entitled (Shirinovskaya, 2017: 27; Minchenko, 2007: 6; Zuev, 2014: 57). Some scholars consider TTNU to be a non-typical form of enjoyment of land and resources (Karakin and Buldakova, 2010: 111), withdrawn from civil circulation with the purpose of overriding negative experience of transfer ring of "tribal lands assigned to indigenous minorities in some territorial entities of Russian Federation to oil and gas producers, including foreign actors, for minimal monetary compensation. Indigenous peoples remained left out" (Danilova, 2009: 39).

In spite of such understanding Russian legislator does not establish TTNU as a form of a property right to land and other natural resources. At the beginning of the 90s, a thought of Russian legislator was aimed at recognising rights of indigenous peoples to land and natural resources, that they have been using for their traditional economic activity for centuries. This met the international standards of protection of rights of indigenous peoples to the fullest extent. For the following 10 years, the Russian government reconsidered its attitude towards the right of indigenous minorities to natural resources. The government prefers to retain these rights. Withdrawal of recognition of property rights of indigenous communities to these lands is one of the main obstacles to ratifying the ILO Convention No. 169 by Russia.

The attitude of the government has also changed towards family and tribal lands, that earlier were considered to be a form of property rights of persons from indigenous peoples, families, and communities to lands of native residence within the borders of TTNU. The courts began to reiterate that tribal lands are territories and not land lots, therefore, they cannot be objects of property rights and re-registering rights to tribal lands into other rights is not allowed (Amirova and Nigmatullina, 2014: 67).

In 2000s TTNU were classified as specially protected nature conservation areas, later - as lands intended for nature protection purposes (Article 94 of the Land Code of the Russian Federation). Currently, the Government of the Russian Federation is suggesting to define them as territories with a special regime of conducting economic activity. TTNU will be formed for 49 years by territorial entities of the Russian Federation on federal lands (or lands in non-delineated state ownership) (Proyekt Federalnogo zakona 2017). Within TTNU indigenous peoples will use natural resources under the agreement with public authorities of a territorial entity on conducting traditional economic activity. Other economic actors (by implication of the explanatory note, these are subsoil users and large timber producers) are also entitled to conduct business operations on these territories under the agreement with public authorities in the region. 
Taking into account the tendencies of a modern legal regulation TTNU shall be viewed as a territorial unit in the territorial division of a territorial entity of the Russian Federation. Therefore, it demonstrates the subject matter of TTNU through a system of categories of territorial division and not through property rights to land and other natural resources.

In a number of territorial entities of the Russian Federation along with municipal and administrative-territorial units, there is a category of territorial units. Territorial units include localities, village councils, specially protected nature conservation areas. Within the borders of municipal and administrative-territorial units, either a body of local self-government or territorial structural departments of bodies of state authorities of an entity of the Russian Federation are created. In contrast, a specific legal regime is established for territorial units. It may be complex, e.g. a regime of a locality as of a territorial unit.

Within the borders of TTNU as in, e.g. the borders of a locality, no public-law entity and special public authorities are created, but a special legal regime of economic management, construction works, use of the objects of water, forest or animals shall be established. It should be noted that for the management of several TTNU special entities are created (e.g. Article 10 of the Law of the Yamal-Nenets Autonomous District).

Considering that TTNU is a territorial unit by nature, it is impossible to agree with suggestions of the Government of the Russian Federation to transform a "legal regime of TTNU" (Proekt) into "conditions of management of TTNU".

It seems to us that a legal regime of TTNU shall be complex and shall be established by a federal legislative body. The principles of a legal regime of TTNU shall include obligatory formation of TTNU in places of native residence of indigenous peoples, recognition of the rights of indigenous peoples to a free use of all land and resources within the borders of TTNU, their zoning funded through the budget, limitation of other economic activity in this territory by types and extent, its prohibition in particular areas, taking into account routes of deer migration (Ronzhina, 2017: 23).

Experience of foreign states (Thomas, 2016: 418), a common practice in some territorial entities of the Russian Federation (Shor National Park) proves the efficiency of the co-administration regime in relation to TTNU (Poddubikov, 2012: 136; Yamskov, 2017: 7). A transition from "paternalism to a partnership" (Koptseva, 2017: 33) will allow solving economic and ecological objectives in the Arctic.

A legal regime of TTNU shall also include a principle, according to which decisions on termination or suspension of forest fire fighting may not be made in relation to such 
territories. Similar ideas are suggested by the Ombudsman for Rights of Indigenous Peoples in Irkutsk Region in connection with the cessation of forest fire extinction, that destroyed 200 thousands hectares of forest in TTNU of Katanga district in 2017 (Postanovlenie 61/28). According to the Rules of Fire Extinction (established by the Order of Ministry of Natural Resources and Environment of the Russian Federation of 8 July 2010 No. 313) public authorities may decide to cease fire extinction, if there is no danger for localities or economical objects in cases when expected losses of forest fire extinction exceed expected damage from the fire.

B. Formation of TTNU. An obligation to create TTNU in places of indigenous residence and traditional economic activity may become one of the significant guarantees of circumpolar civilisation peoples' rights to a traditional way of life. Borders of TTNU shall be determined by a law of a territorial entity of the Russian Federation considering two factors. Firstly, based on a historically developed scheme of natural resources use in places of native residence of indigenous peoples and their traditional economic activities these are territories actually used by indigenous communities, families, and people. Thus, public authorities of Irkutsk and Magadan Regions, when confirming land-use planning schemes, acknowledge the existence of lands actually used by indigenous communities for their traditional economic activity (reindeer husbandry, fishing, hunting) and that they shall be established as TTNU (Postanovlenie 607). It is suggested to conduct an "analysis of reindeer migration routes and cattle-stations used by them in different seasons" when working on TTNU projects (Zuev, 2016: 55).

Secondly, it shall be noted that in many territorial entities of the Russian Federation there is a necessity of the update of the list of places of traditional nature use and traditional economic activity, established by the Government of the Russian Federation of 8 May 2009 No.631-r. (Doklad Upolnomochennogo po pravam..., 2017). Therefore, it is possible to form TTNU that will include lands available for conducting traditional economic activity, also lands subject to assignation to indigenous peoples instead of lands they lost as a result of forced migration. The right to initiate a procedure of establishing TTNU and its boundary adjustment shall be reserved by local government authorities, indigenous peoples, and their communities.

C. A subject of traditional nature use within the borders of TTNU. A legal uncertainty about determination and changing of an actor conducting traditional nature management in TTNU remains. It is necessary to define such subject not only in order to prevent disputes between communes and indigenous persons, expected 
by some scholars (Filant, 2016: 88). Such disputes are not reported, on the contrary, there are records of shared use of one territory by several communes. Thus, Evenkis nomadic ancestral communes "Boota" and "Goya" do not legally own any land and shepherd their deer on lands belonging to a commune "Hatystyr" (Savvinova et al., 2015: 40).

A legal definition of a subject of traditional nature use within TTNU is necessary for realisation of a legal faculty of protection of property rights and other rights to the use of land and other natural resources, including protection against actions of public authorities, and for representing interests of indigenous minorities during negotiations with mining, lumber and road companies (Vlasova, Kaplin, Volkov, 2018: 12).

Regional practice on defining a subject, whose interests determine the creation of TTNU, is ambiguous. Thus, the List of TTNU of indigenous peoples of the North of a regional significance in Khanty-Mansi Autonomous District Yugra contains personal information of subjects of traditional nature use. For this reason, the following judicial practice is particularly interesting. The father of an administrative claimant Novoselov, an ethnic Mansi, rented tribal lands of 44 hectares within the borders of TTNU (K-33). After his death, his son was denied in registration as a subject of a right of traditional nature use in TTNU (K-33). The Court obliged authorities to include into the List of TTNU the information about the son of Novoselov as a subject of traditional nature use of K-33 because during the court proceeding he confirmed the fact of living and conducting economic activity within this TTNU (Reshenie 10.05.2017).

It seems that the legislation should define subjects that are entitled to use land and other natural resources within TTNU (indigenous persons, indigenous families, nomadic families, communes, persons who are not indigenous but constantly living in TTNU and using natural resources for their personal needs, if this does not violate the legal regime of TTNU) and additional subjects who are entitled to enforce, represent and protect their interests (e.g. unions and associations of indigenous peoples).

D. "Overlapping" and "crossing" of borders of TTNU with other territorial units. The problem of territorial units crossing is still unregulated, but denial of such possibility is not articulated. This matter is especially of current interest in the part of crossing between the borders of TTNU and the borders of specially protected nature conservation territories. Thus, a special area of traditional, extensive nature use is created in the Shor specially protected nature conservation territory. On this territory for people permanently resident in several localities, it is allowed to conduct traditional economic activity (including hunting, fishing, mowing, pasturage of animals, 
construction of ethnic traditional houses and other buildings necessary for conducting traditional economic activity).

However, in a majority of cases, the practice of TTNU and specially protected nature conservation territories border-overlapping and interference of their legal regimes is negatively accessed. For example, the formation of an "Udegeyskaya Legenda" national park in Primorski Region caused deprivation of indigenous peoples (Gogolev, Gogolev, Maiakunov 2017: 18). Taking into account cultural and historical value of hunting as part of the ethnic culture of Shor people, it is considered to be unreasonable to establish closely guarded territories of a Shor national park particularly in areas where traditional hunting has been taking place for centuries. When establishing a national park no attention was paid to peculiarities of economic organisation of the native population. Similar problems, connected to traditional economic practices of local residents, are usual for specially protected nature conservation territories of Altai and Sayan regions. Local groups of Tubalars, for example, have no opportunity to fish in resourceful water areas of Teletskoye Lake because of restrictions imposed by Altai State Biosphere Reserve (Poddubikov, 2012: 138).

E. Property rights to land and natural resources of indigenous peoples as one of the elements of a legal regime of TTNU. With the end of the period of "romantic" attitude of Russian state authorities towards indigenous peoples, norms about the free use of land and other natural resources within TTNU disappeared from the federal legislation. Historically, traditional nature use was complex, it did not require special authorisation and was not subject to a rigorous control. Current legislation, even though containing general provisions on the traditional use of natural resources by indigenous minorities, still requires special authorisation and licensing in relation to every type of resources. It is underlined that "leasing relationship is not quite appropriate in this case as well, because it requires express identification of a land lot as an object of rights, whereas it is hardly possible with regard to reindeer pasture fields. Moreover, the lease is reciprocal in nature, which does not fit the concept of traditional nature use" (Grigorieva, 2016: 42-43).

An obligation to sign an agreement on conducting the activity within the borders of TTNU is added to the existing authorisation and licensing system by amendments to FL49 suggested by the Government of the Russian Federation. It is not proposed to revise Article 39.33 of the Land Code according to which indigenous persons may be entitled to use land lots without their assignation, which means without their determination, and without establishing servitude. However, such rights are ceased in a summary procedure 
starting from the day public authorities make a decision on assigning a particular land lot to another person or an entity (Article 39.34(2) of a Land Code).

Proposals to recognise rights of indigenous peoples to land, to abolish the use of natural resources based on payment, authorisation and licensing, including one on the basis of tenders, are reasonable. They comply with the concept of recognising specific rights of indigenous peoples to land used for conducting traditional economic activity. Rights of indigenous minorities to land and natural resources within the areas of their native residence are different from other widely-used forms of property as they imply a specific subject, a unique object of an assertion of right and the peculiarity of a legal regime of collective possession, use, and disposal in relation to such object. Such specific right is essentially characterised on the one hand, by its ethno-communal nature and restrictions of legal faculties of the right's user (Prochazka, 2017: 78), and by higher protection on the other hand.

Conclusion. The research undertaken allows to substantially revise the legal nature of "a territory of traditional nature use" as a legal category and the principles of its legal regime. We suppose that the projected reform of the legal status of TTNU shall consider the following:

1. TTNU is a territorial unit in the territorial division of a territorial entity of the Russian Federation. Borders of TTNU may cross other territorial units, e.g localities or specially protected nature conservation territories. "Overlapping" or "crossing" of legal regimes of territorial units shall be regulated at the federal level.

2. The legal regime of TTNU requires complex statutory regulations including obligatory formation of such territorial units in places of native residence of indigenous peoples with regard to the actual use of land and other natural resources for conducting traditional economic activity, and also creation on a federal level of a set of constraints in economic activity of other actors, primarily, subsoil users and timber producers, within the borders of TTNU.

3. FL-49 shall determine types of traditional economic actors entitled to conduct use of natural resources within TTNU and their legal status.

4. A special property right - an ethno-communal form of ownership (another form of ownership provided by Article 9(2) of the Constitution of the Russian Federation) of indigenous peoples on land and other natural resources within TTNU that implies a specific range of legal faculties for relevant subjects, shall be recognised. Therefore, the complete abolition of the use of natural resources based on payment, authorisation and licensing for indigenous peoples within TTNU, is reasonable. 


\section{References}

Amirova, R.R., Nigmatullina, E.F. (2015). Konstitutsionno-pravovaya politika v sfere zashchity ekologicheskikh prav korenyikh malochislennykh narodov Rossii [Constitutional and Legal Policy in the Sphere of Protection of Ecological Rights of Indigenous Peoples of Russia], In Yuridicheskiy mir [The Legal World], 3, 5-10.

Andrichenko, L.V. (2014). Pravovaia reglamentatsiia statusa korennykh malochislennykh narodov Severa Rossii [Legal Regulation of the Status of Indigenous Peoples of the North of Russia], In Rossiyskaia Arktika-territoriia prava [The Russian Arctic - the Territory of Law]. Salekhard.

Byurgorg-Larsen, L. (2014). Pozitivniie obyazatelstva v praktike organov Mezhamerikanskoy sistemy zashchity prav cheloveka [Positive Obligations in the Practice of the Inter-American System of Bodies on the Human Rights Protection], In Mezhdunarodnoye pravosudiye [International Justice], 2, 106-121.

Danilova, N.V. (2008). K voprosu o zemelnykh pravakh korennykh malochislennykh narodov Rossii [On the Land Rights of the Indigenous Populations of Russia], In Vestnik Permskogo universiteta. Yuridicheskiie nauki [Bulletin of Perm University. Law], 1, 64-66.

Danilova, N.V.(2009). Pravovoy rezhim territoriy traditsionnogo prirodopolzovaniia korennykh malochislennykh narodov [The Legal Regime in the Territories of Traditional Nature Management Inhabited by Indigenous Peoples], In Yuridicheskaia nauka $i$ pravookhranitelnaia praktika [Juridical Science and Practice of Law Enforcement], 4(10), 35-42.

Deklaratsiya Organizatsii Obyedinennykh Natsiy o pravakh korennykh narodov, utv. rezolyutsiyei 61/295 Generalnoy Assamblei OON ot 13.09.2007 [The United Nations Declaration on the Rights of Indigenous Peoples, United Nations General Assembly Resolution 61/295]. Available at: http://www.un.org/ru/documents/decl conv/declarations/indigenous_rights.shtml

Doklad Upolnomochennogo po pravam korennykh malochislennykh narodov $v$ Krasnoyarskom kraie ot 06.06.2016 "O problemakh realizatsii konstitutsionnykh prav $i$ svobod korennykh malochislennykh narodov na territorii Krasnoyarskogo kraya v 2015 godu [The Report of the Commissioner for the Rights of Indigenous Peoples in Krasnoyarskiy Krai dated on June 06, 2016 "On the Problems of Implementing the Constitutional Rights and Freedoms of Indigenous Minorities in the Territory of Krasnoyarskiy Krai in 2015”], SPS Consultant.

Doklad Upolnomochennogo po pravam korennykh malochislennykh narodov $v v$ Respublike Sakha (Yakutiya) ot 25.04.2017 g. "O soblyudenii prav i zakonnykh 
interesov korennykh malochislennykh narodov Severa Respubliki Sakha (Yakutiya) [The Report of the Commissioner for the Rights of Indigenous Peoples of the North in the Republic of Sakha (Yakutiya) dated on April 25, 2017 "On the Observance of the Rights and Legal Interests of Indigenous Peoples of the North of the Republic of Sakha (Yakutia)"'], SPS Consultant.

Federalnyi Zakon ot 07.05.2001g. № 49-Ф3 (v red. ot 31.12.2014) "O territoriyakh traditsionnogo prirodopolzovaniia korennyk malochislennykh narodov Severa, Sibiri i Dal'nego Vostoka Rossiiskoi Federatsii" [Federal Law on May 07, 2001, No. 49Ф3 (as amended on December 31, 2014) "On Territories of Traditional Nature Use Inhabited by Indigenous Peoples of the North, Siberia and Far East of the Russian Federation"], SPS Consultant.

Filant, K.G. (2016). Ob obrazovanii territoriy traditsionnogo prirodopolzovaniia korennykh malochislennykh narodov severa $\mathrm{v}$ Yamalo-Nenetskom avtonomnom okruge [On the Formation of the Traditional Nature Use Territories Inhabited by Indigenous Peoples of the North in Yamalo-Nenets Autonomous Okrug], In Problemy sovremennoy nauki i obrazovaniya [Problems of the Modern Science and Education], 39(81), 83-92, DOI: 10.20861/2304-2338-2016-81-003.

Gogolev, P.V., Maiakunov, A.E. (2017). Zemlya kak kategoriia konstitutsionnopravovoy politiki i obshchestvennogo diskursa $\mathrm{v}$ kontekste traditsionnogo prirodopolzovaniia korennykh malochislennykh narodov Severa, Sibiri i Dalnego Vostoka [The Earth as a Category of Constitutional and Legal Policy and Public Discourse in the Context of Traditional Nature Management of Indigenous Peoples of the North, Siberia and the Far East], In Gosudarstvennaia vlast' $i$ mestnoie samoupravleniie [The State Power and Local Self-Government], 10, 13-19.

Grigorieva, M.V (2016). Nekotoryie pravovyie problemy traditsionnogo prirodopolzovaniia korennykh malochislennykh narodov Severa, Sibiri i Dalnego Vostoka [Some Legal Problems of Traditional Environmental Management by Indigenous Peoples of the North, Siberia and Far East], In Sotsialno-ekonomicheskiy i gumanitarniy zhurnal Krasnoyarskogo GAU [Socio-Economic and Humanitarian Journal of Krasnoyarsk State Agrarian University], 3, 39-46.

Iakel', Yu.Ya. (2012). Obshchaia kharakteristika deistvuyushchego zakonodatelstva. Problemy praktiki primeneniia [General Review on the Current Legislation. Problems of Practice], In Sever i severiane. Sovremennoye polozheniie korennykh malochislennykh narodov Severa, Sibiri i Dalnego Vostoka [The North and Northerners. The Current Situation Around Indigenous Peoples of the North, Siberia and the Far East], Moscow, IEA RAS. 
Indigenous Peoples: a global quest for justice. The report for the Independent Commission on International Humanitarian Issues (1987). London, Atlantic Highlands.

Karakin, V.P., Buldakova, V.G. (2010). Traditsionnoye prirodopolzovaniie na Rossiyskom Dalnem Vostoke [Traditional Nature Management in the Russian Far East], In Rossiya i ATR [Russia and the Asia-Pacific Region], 3, 102-115.

Konventsiia MOT № 169 "O korennykh narodakh i narodakh, vedushchikh plemennoy obraz zhizni v nezavisimykh stranakh" ot 27.06 .1989 (ne ratifitsirovana Rossiiskoi Federatsiyei) [ILO Convention No. 169 "On Indigenous and Tribal Peoples in Independent Countries" dated on June 27, 1989 (not ratified by the Russian Federation)], SPS Consultant.

Koptseva, N.P. (2017). Ekspertnaia otsenka ekologicheskoy situatsii, kharakternoy dlia korennykh narodov malochislennykh narodov Sibirskoy Arktiki (na primere Krasnoyarskogo kraya) [Expert Environmental Assessment, Specific for Indigenous Peoples of Siberian Arctic (on the Basis of Krasnoyarsk Region)], In Ekologiya cheloveka [Human Ecology], 6, 30-35.

Korennyie i malochislennyye narody Severa i Sibiri v usloviyakh globalnoy transformatsii (na materiale Krasnoyarskogo kraya) [Indigenous and Small Peoples of the North and Siberia Under the Conditions of Global Transformation (based on the material of Krasnoyarskiy Krai)] (2012). Krasnoyarsk, SFU.

Kryazhkov, V.A. (2015). Konstitutsionno-pravovyie statusy finno-ugorskikh narodov v Rossiyskoy Federatsii [Constitutional and Legal Statuses of Finno-Ugric Peoples in the Russian Federation], In Konstitutsionnoye i munitsipalnoye pravo [The Constitutional and Municipal Law], 5, 24-32.

Kurikov, V.M.,Dyatlova,T.A.,Khaknazarov,S.Kh.(2016). Sotsialno-ekonomicheskiie problemy razvitiia korennykh malochislennykh narodov Severa Khanty-Mansiyskogo Avtonomnogo Okruga - Yugry [The Socio-Economic Problems of the Development of Indigenous Peoples of the North of the Khanty-Mansiysk Autonomous Okrug - Ugra], In Kulturnoie naslediie traditsionnykh soobshchestv v kontekste mirovoy tsivilizatsii: problemy perevoda i mezhkulturnogo dialoga. Materialy Vserossiyskoy nauchnoy konferentsii (s mezhdunarodnym uchastiyem), posvyashchennoy 60-letnemu yubileiu SVFU im. M.K. Ammosova [The Cultural Heritage of Traditional Communities in the Context of World Civilization: Problems of Translation and Cross-Cultural Dialogue: the Proceedings of the All-Russian Scientific Conference (with international participation) Dedicated to the 60th Anniversary of the Noerth-Eastern Federal University in Yakutsk], Yakutsk, Izdatelskiy dom SVFU, 70-98. 
Novikova, N.I. Iakel', Yu.Ya. (2006). Sudebnaia zashchita prava na traditsionnoye prirodopolzovaniie: antropologo-pravovyie aspekty [Judicial Protection of the Right for Traditional Nature Management: Anthropological and Legal Aspects], Moscow, Institute of Ethnology and Anthropology, 38 p.

Obzor. Na soveshhanii gubernatora Yugry obsudili problemy neftyanikov i korennykh narodov Severa (2011) [The Review. At the meeting of the governor Ugra discussed the problems of oil producers and indigenous peoples of the North]. In Econadzor. Available at: http://econadzor.com/news/386.html

Parra, V.O., Tarre, M.P. (2016). Obzor sudebnoy praktiki Mezhamerikanskogo suda po pravam cheloveka za 2015 god [The Review of Judicial Practice of the Inter-American Court of Human Rights for 2015], In Mezhdunarodnoye pravosudiie [International Justice], 2, 3-16.

Poddubikov, V.V. (2012). Korennyie malochislennyie etnosy Altaye-Sayanskogo regiona: traditsionnoye prirodopolzovaniye i pozemelnyie otnosheniia $\mathrm{v}$ rakurse problem mezhetnicheskoy tolerantnosti [Indigenous Minorities of the Altai-Sayan Region: Traditional Nature Management and Land Relations Within the Problems of Interethnic Tolerance], In Vestnik arkheologii, antropologii i etnografii [Bulletin of Archeology, Anthropology and Ethnography], 2, 136-143.

Postanovleniie Pravitelstva Irkutskoy oblasti ot 02.11.2012 № 607-pp (red. ot 31.08.2016) "Ob utverzhdenii skhemy territorialnogo planirovaniia Irkutskoy oblasti" [The Decree of the Government of Irkutskaya Oblast dated on November 02, 2012 No. 607-pp (as amended on August 31, 2016) "On Approval of the Territorial Planning Scheme for Irkutskaya Oblast”], SPS Consultant.

Postanovleniie Pravitelstva Krasnoyarskogo kraia "Ob utverzhdenii poriadka obrazovaniia territoriy traditsionnogo prirodopolzovaniia korennykh malochislennykh narodov Rossiyskoy Federatsii, prozhivayushchikh na territorii Krasnoyarskogo kraia, krayevogo (regionalnogo) znacheniia i perechnya dokumentov, neobkhodimykh dlia prinyatiia resheniia ob obrazovanii territorii traditsionnogo prirodopolzovaniia korennykh malochislennykh narodov Rossiyskoy Federatsii, prozhivayushchikh na territorii Krasnoyarskogo kraia, kraievogo (regionalnogo) znacheniia" ot 18.07.2017 № 421 [The Resolution of the Government of the Krasnoyarskiy Krai "On the Approval of the Procedure on Forming the Territories of Traditional Nature Management of Indigenous Peoples of the Russian Federation Inhabiting the Territory of Krasnoyarskiy Krai, the Krai (regional) Value and the List of Documents Required to Confirm the Formation of the Territory of Traditional Nature Use Belonging to Indigenous Peoples 
of the Russian Federation Inhabiting Krasnoyarskiy Krai of Regional Importance dated on July 18, 2017 No. 421], SPS Consultant.

Postanovleniie Zakonodatelnogo Sobraniya Irkutskoy oblasti ot 18 aprelia 2018 g. № 61/28-ZS "O doklade Upolnomochennogo po pravam cheloveka v Irkutskoy oblasti o polozhenii $v$ sfere soblyudeniya prav $i$ svobod cheloveka $i$ grazhdanina v Irkutskoy oblasti v 2017 godu" [The Resolution of the Legislative Assembly of Irkutskaya Oblast dated April 18, 2018 No. 61/28-3C "On the Report of the Commissioner for Human Rights in Irkutskaya Oblast on the Situation in the Sphere of Observance of Human and Civil Rights and Freedoms in Irkutskaya Oblast in 2017”], SPS Consultant.

Postanovleniyie Pravitelstva Irkutskoy oblasti ot 29.12.2014 g. № 704-pp "Ob obrazovanii territorii traditsionnogo prirodopolzovaniia korennykh malochislennykh narodov Severa, Sibiri i Dal'nego Vostoka Rossiiskoy Feedratsii, prozhivayushchikh na territorii Irkutskoy oblasti, regionalnogo znacheniya, raspolozhennoy na territorii munitsipalnogo obrazovaniia "Kachugskiy rayon" [The Decree of the Government of Irkutskaya Oblast No. 704-pp dated on December 29, 2014 "On the Formation of the Territory of Traditional Nature Management of the Indigenous Peoples of the North, Siberia and the Far East of the Russian Federation, Residing on the Territory of Irkutskaya Oblast, of Regional Importance Located in the Territory of the Municipal Entity "Kachugsky District”], SPS Consultant.

Prochazka, J. (2017). Back to its Roots: How $§ 1983$ Must Return to its Origins to Provide a Remedy for the Inupiat Against Oil Drilling in Alaska's Arctic Circle, In Nw. J. L. \& Soc. Pol'y (12). Available at: http://scholarlycommons.law.northwestern.edu/ njlsp/vol12/iss $3 / 5$

Proyekt Federalnogo zakona ot 31.05.2017 g. "O vnesenii izmeneniy v Federalniy zakon "O territoriiakh traditsionnogo prirodopolzovaniia korennykh malochislennykh narodov Severa, Sibiri i Dal'nego Vostoka Rossiyskoy Federatsii”, a takzhe otdelnyie zakonodatelnyie akty Rossiyskoy Federatsii (vnesen Pravitelstvom Rossiyskoy Federatsii) [Draft Federal Law on May 31, 2017 “On Amending the Federal Law "On the Territories of Traditional Nature Management of Indigenous Peoples of the North, Siberia and the Far East of the Russian Federation", as well as Certain Legislative Acts of the Russian Federation (introduced by the Government of the Russian Federation)], Available at: http://regulation.gov.ru/projects \#npa $=66793$

Ragulina, M.V. (2009). Traditsionnyie sposoby zhizneobespecheniia evenkov Pribaykalia [Traditional Methods of Life Sustaining of the Evenks in the Baikal 
Region], In Geografiya i prirodnye resursy [Geography and Natural Resources], 2, $109-116$.

Resheniie Nizhneudinskogo gorodskogo suda Irkutskoy oblasti ot 30.09.2015 g. po delu № 2-1125-15 po isku ob obyazanii tofalarskoy obshchiny "Irbis" ustranit' narusheniia lesnogo zakonodatelstva putiom osvobozhdeniia lesnogo uchastka ot dereviannogo doma razmerami $4 x 5 \mathrm{~m}$. [The Decision of the Nizhneudinsk Town Court of Irkutskaya Oblast on Case No. 2-1125-15 on the Suit Obliging the Tofalar Community "Irbis" to Remedy the Failures of the Forest Legislation by Elimination of the Wooden House $4 x 5$ m, dated on September 30, 2015], SPS Consultant.

Resheniie ot 24.12.2014 g. Nizhneudinskogo gorodskogo suda Irkutskoy oblasti po delu № 2-1247-14; Apellyatsionnoye Opredeleniie ot 25.03.2015 goda po delu № 33-2375/2015 [The Decision of the Nizhneudinsky City Court of Irkutskaya Oblast on Case No. 2-1247-14 dated on December 24, 2014; Appellate Ruling on March 25, 2015 on Case No. 33-2375 / 2015], SPS Consultant.

Resheniye Kondinskogo rayonnogo suda Khanty-Mansiyskogo avtonomnogo okruga - Yugry ot 10.05.2017 g. po delu № 2a-323/2017 ob obzhalovanii otkaza Komissii po voprosam territoriy traditsionnogo prirodopolzovaniia Departamenta prirodnykh resursov i nesyrievogo sektora ekonomiki KHMAO-Yugry s zayavleniyem o vklyuchenii svedeniy o $n e m v$ Reyestr territoriy traditsionnogo prirodopolzovaniia korennykh malochislennykh narodov Severa regionalnogo znacheniia v KHMAO - Yugre, kak o subiekte prava traditsionnogo prirodopolzovaniia K-33 [The Decision of the Kondinskiy District Court of Khanty-Mansiysk Autonomous Okrug - Ugra on May 10, 2017 in the Case No. 2a323/2017 On Appealing Against the Refusal of the Commission on Territories of Traditional Nature Management of the Department of Natural Resources and Non-Commodity Sector of Economics of Khanty-Mansiysk Autonomous Okrug - Ugra With Request to Include Information in the Register of Territories of Traditional Nature Management of Indigenous Minorities of the North of Regional Importance in KhMAO-Ugra as the Subject of the Law of Traditional Nature Management of K-33], SPS Consultant.

Resheniye ot 21.02.2014 g. Yelizovskogo rayonnogo suda Kamchatskogo kraia po zayavleniiu Aleutskoy nekommercheskoy organizatsii "Rodovaia obshchina "KIGNAKH" (Ogon) na bezdeystviie Glavy Aleutskogo munitsipalnogo raiona i Nikolskogo selskogo poseleniia) [The Decision of Elizovsky District Court of Kamchatskiy Krai On the Claim of the Aleut Non-Profit Organization KIGNAKH Community (Ogon') For Inaction of the Head of Aleutskiy Municipal District and Nikolsky Rural Settlement dated on February 21, 2014], SPS Consultant. 
Ronzhina, O.V. (2017). Pravo korennykh narodov na zemli v granitsakh territorii iskonnogo prozhivaniia (pravo sobstvennosti na zemliu $\mathrm{v}$ svete tsirkumpolyarnoy teorii) [The Right to Land of Indigenous People on the Territories of Ancestral Residence (Property Rights to Land Under the Circumpolar Theory)], In Problemy konstitutsionno-pravovogo regulirovaniia statusa arkticheskikh territoriy Rossiyskoy Federatsii: materialy kruglogo stola mezhdunarodnoy nauchno-prakticheskoy konferentsii [Problems of Constitutional and Legal Regulation of the Status of Arctic Territories of the Russian Federation: Materials of the Round table of the International Scientific and Practical Conference], Krasnoyarsk.

Savvinova, A.N., Filippova, V.V., Gnatyuk, G.A., Svinoboyeva, A.Yu., Fedorova, A.S., Diachkovskiy, G.Ye. (2015). Zemlepolzovaniie evenkov Belletskogo naslega v usloviyakh promyshlennogo osvoyeniia Yuzhnoy Yakutii [The Land Use of the Evenks of Belletskiy Nasleg Under Industrial Development of the Southern Yakutia], In Arktika XXI vek. Yestestvennyie nauki [The Arctic of the 21 ${ }^{\text {st }}$ Century. Natural Sciences], 1 (2), $38-43$.

Shirinovskaya, A.S. (2017). Osobennosti subiektivnogo prava na zemlyu v konstitutsionno-pravovom aspekte [The Features of Subjective Right to Land in Constitutional and Legal Aspects], In Elektronnoye prilozheniie $k$ Rossiyskomu yuridicheskomu zhurnalu [Electronic Supplement to the Russian Legal Journal], 2, 27-36.

Thomas, C.S. (2016). Alaska Politics and Public Policy. The Dynamics of Beliefs, Institutions, Personalities, and Power. University of Alaska Press.

Tranin, A.A. (2010). Territorii prirodnogo prirodopolzovaniia korennykh malochislennykh narodov rossiyskogo Krainego Severa (problemy i perspektivy) [The Territories of Natural Use Inhabited by Indigenous Peoples of the Russian Far North (Problems and Prospects)], Moscow, IGP RAN, 213 p.

Ukaz Prezidenta Rossiiskoi Federatsii ot 22.04.1992g. № 397 “O neotlozhnykh merakh i zashchite mest prozhivaniia i hoziaistvennoi deiaatelnosti malochislennykh narodov severa” [Presidential Decree on April 22, 1992. No. 397 “'On Urgent Measures and Protection of Habitation and Economic Activities of Indigenous Peoples of the North] (1992). In Bulletin of Congress of People's Deputies of the Russian Federation, (18).

Vlasova,T.V, Kaplin, N.S, Volkov, S.G. (2018). Sotsiomonitoring konfliktnykh problem traditsionnogo prirodopolzovaniya $\mathrm{V}$ Evenkii na primere sotsialnoekologicheskoy sistemy lesopolzovaniya [Sociomonitoring of Conflictual Problems on Traditional Nature Management in Evenkiya Through the Example of the Socio- 
ecological System of Forest Management], In Biosfernoye khoziaystvo: teoriia $i$ praktika [Biosphere Economy: Theory and Practice], 1 (4), 5-16.

Yamskov, A.N. (2017). Vozmozhnyie dopolnenia definitsii "territoriy traditsionnogo prirodopolzovaniia" korennykh narodov Severa v sviazi s gotoviashchimisia novymi federalnymi zakonami [Possible Additions to the Definition of "Territories of Traditional Nature Management" Inhabited by Indigenous Peoples of the North Related to Forthcoming New Federal Laws], In Biosfernoye khozyaystvo: teoriya i praktika [Biosphere Economy: Theory and Practice], 1 (2), 5-13.

Zakon Yamalo-Nenetskogo avtonomnogo okruga ot 21.04.2010 g. "O territoriiakh traditsionnogo prirodopolzovaniia regionalnogo znacheniia v Yamalo-Nenetskom avtonomnom okruge” [The Law of Yamal-Nenets Autonomous Okrug dated on April 21, 2010 "On the Territories of Traditional Nature Management of Regional Importance in Yamal-Nenets Autonomous Okrug”'], SPS Consultant.

Zuev, S.M. (2014). Territorii traditsionnogo prirodopolzovaniia kak osnova pravovogo regulirovaniia zemelnykh otnosheniy korennykh malochislennykh narodov Severa (na primere YANAO) [The Territories of Traditional Nature Management as the Basis for Legal Regulation of Land Relations of Indigenous Peoples of the North (through the example of YaNAO)], In Nauchnyy vestnik YANAO [Scientific Bulletin of Yamalo-Nenets Autonomous Okrug], 2 (83), 55-63.

\title{
Территория традиционного природопользования как отдельная территориальная единица \\ в системе территориального деления Севера, Сибири и Дальнего Востока России
}

\author{
А.А. Кондрашев, О.В. Роньжина, А.Б. Зенкина \\ Сибирский федеральный университет \\ Россия, 660041, Красноярск, пр. Свободный, 79
}

\footnotetext{
Новые проекты Правительства Российской Федеращии по реорганизации территорий традиционного природопользования коренных малочисленных народов становятся предметом анализа и дискуссий в научном сообществе. При помощи сравнительных методов, используемых в области права, рассматривается правовая модель федеральной, региональной и муниципальной территорий традиционного природопользования. Применяя методы статистического анализа, авторы раскрывают современные тенденции в фактической реализации прав коренных нардов на использование земли
} 
и других природных ресурсов в этих зонах и на тех территориях их коренного проживания, которые официально не признаны территориями традиционного природопользования. Учитывая современную экономическую обстановку в России, нацеленную на увеличение добычи ресурсов Севера, необходимо поддерживать реализачию прав коренных меньшинств, гарантированных статьей 69 Конституции Российской Федерации. В частности, говоря о федеральном уровне, необходимо определить общие базовые характеристики правового режима территории традиционного природопользования, подобно режиму административного субъекта Российской Федерации. Комплексный правовой режим упомянутых территорий должен подразумевать обязательное формирование территориальных единии в поселениях коренных народов с учетом системы земле- и природопользования, принятой в рамках традиционной экономики, наряду с ужесточением правил для экономической деятельности других исполнителей, прежде всего разработчиков недр и производителей древесины, на территориях традиционного природопользования. В декларации о правах на отдельные виды собственности закрепляется этнообщинная, нерыночная форма собственности на землю и другие природнье ресурсы для коренных народов (другая форма собственности прописана в статье 9(2) Конституциии Российской Федеращии).

Ключевые слова: коренные народы, территории традиционного природопользования, Арктический регион, территориальное деление, форма собственности.

Статья представляет собой часть исследования № 17-13-24004 «Правовое регулирование государственного и мунищипального деления Северных территорий Красноярского края (включая территории постоянного проживания коренных народов), ориентированное на их стабильное сочиильное и экономическое развитие» в рамках гранта, предоставленного Российский фондом фундаментальных исследований, при поддержке Правительства Красноярского края, Красноярского краевого фонда поддержки науки и техники, а также правовом консультировании системь «Консультант-Плюс».

Научная специальность: 12.00.00 - юридические науки. 